\title{
From the Plague to the Coronavirus: Islamic Ethics and Responses to the COVID-19 Pandemic
}

\author{
Ayman Shabana* \\ Georgetown University in Qatar, Doha, Qatar \\ as2432@georgetown.edu
}

\begin{abstract}
This paper examines some of the important ethical questions that emerged in connection with the CoviD-19 pandemic in light of the various Muslim responses to this global emergency. It focuses on the ethical discussions concerning the main measures that have been taken to fight the disease, which can be divided into two main categories: preventive and therapeutic. The paper also addresses measures taken to handle the dead bodies of deceased patients in a proper and dignified manner, according to relevant Islamic norms. The paper traces the background of these discussions in classical normative discourses, with a particular focus on the issue of the plague and also the issue of medical treatment. The paper argues that Islamic responses to the Covid19 pandemic echo a longstanding two-pronged moral concern in the Islamic normative tradition with regard to pandemic situations; namely, to balance: the religious and metaphysical dimensions of the scriptural sources with the practical implications of real incidents of plagues and pandemics; and the interests of individuals against the collective interests of groups and societies.
\end{abstract}

\section{Keywords}

bioethics - Coronavirus - CoviD-19 - fatwās - Islam - Islamic law and ethics pandemic - plague

* An earlier draft of this paper was presented at a panel entitled "The Covid-19 Pandemic: Historical and Cultural Perspectives," which was part of the Pandemic Panels, organized by Georgetown University in Qatar (May 19-21, 2020). I would like to thank Dean Ahmad Dallal for convening these panels and for giving me the opportunity to present that draft. 


\title{
من الطاعون لفيروس الكورونا: الأخلاقيات الإسلامية والردود المتعلقة بمائحة كوفيد-19 الطون لميرون
}

\author{
أيمن شبانة \\ جامعة جورجتاون في قطر، الدوحة، قطر
}

يتناول البحث بعض الأسئلة الهامة التي واكبت ظهور جائحة كوفيد-19 في ضوء الردود الإسلامية

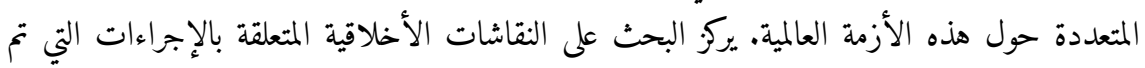

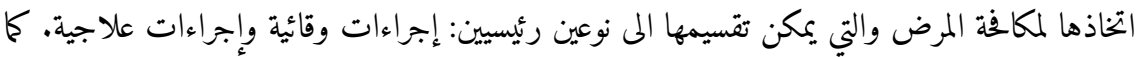

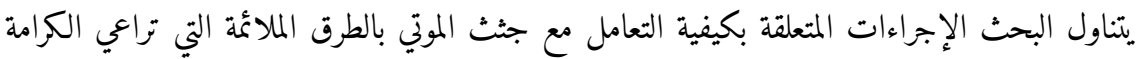

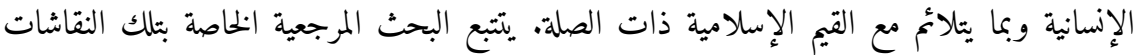

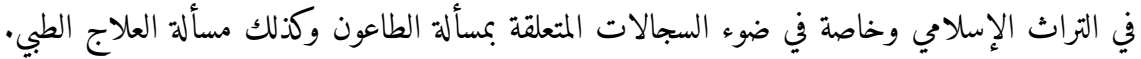

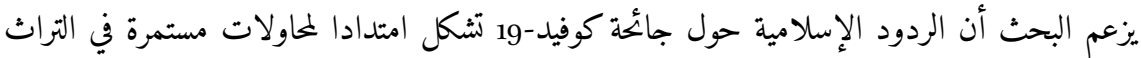

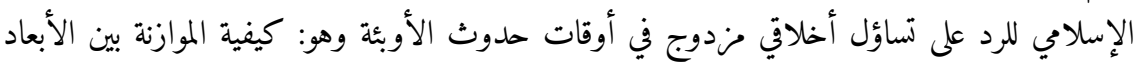

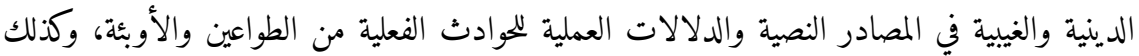

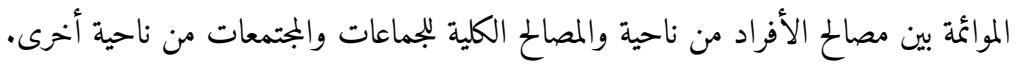

\section{الكلمات المفتاحية}

الأخلاقيات الحيوية - فيروس كورونا المستجد - كوفيد-19 - فتاوى - الإسلام - الفقه والأخلاقيات الإسلامية - الوباء - الطاعون

I would like also to express my gratitude to the anonymous reviewers for their constructive feedback and to the editorial board and office of the Journal of Islamic Ethics for all the hard work throughout the publication process. Research for this project was supported by a Faculty Research Grant from Georgetown University in Qatar. I alone bear full responsibility for the content of this paper. 


\section{Introduction}

The outbreak of the Coronavirus in the early months of 2020 proved to be one of the most transformative events in the modern period. It was first detected in China in December 2019, where several cases of unusual pneumonia were discovered in the city of Wuhan. On January 7 , health officials linked these cases to a newly identified virus that belongs to the family of Coronaviruses, which was named Covid-19 (short for coronavirus disease 2019). China reported its first death as a result of the new virus on January 11 and the second on January 17, as the disease started to spread quickly outside China in the following days. The World Health Organization urged governments to take appropriate measures to fight the disease in the middle of global anxiety over the steadily increasing numbers of positive cases. The international organization eventually designated the COVID-19 outbreak a pandemic on March 11 (wHO 202oa; Taylor 2020 ). By mid-August 2020 the number of confirmed cases globally reached 20 million and the number of confirmed deaths was more than seven hundred thousand, as the numbers kept increasing. By mid-February 2021 the number of confirmed cases was over 110 million and the number of confirmed deaths was close to 2.5 million (WHO 2O2O-2O21). Prior to this coronavirus pandemic the world witnessed several succeeding episodes of devastating pandemics both in the pre-modern and modern periods. The closest example of comparable magnitude in the modern period was the influenza pandemic (HiN1 virus) that spread worldwide in 1918-1919, which is known as the Spanish Flu. It is estimated that about 500 million people, about one third of the world's population, were infected by the virus and it eventually claimed the lives of about 5 o million people worldwide (CDC n.d.).

Pandemics constitute a prominent theme in world history, considering the massive and multifaceted impact that such incidents have had both at the individual and collective levels. The most famous example of pandemics in the pre-modern period was the plague, which repeatedly struck most of Europe and the Near East in successive waves across the centuries. Historians usually refer to three main plague pandemics, with subsequent recurrences, in different regions: the Plague of Justinian, in mid-sixth century; the Black Death, in mid-fourteenth century; and the Bombay Plague, in the late nineteenth century (Dols 1974). ${ }^{1}$ Testimonies in historical chronicles, including graphic descriptions of the grievous consequences of these plagues, reveal the global impact of these phenomena and the extent to which they were not

1 Recent historical studies question the accuracy of grand narratives of pre-modern pandemics on the basis of scientific, mainly genetic, evidence (Green 2014). 
limited to certain geographical areas. From a historical perspective, pandemics have impacted human history in many different ways. As much as they often had painful and tragic effects, they also reveal the human capacity to cope with difficult and challenging circumstances. In the Islamic tradition there is a significant body of literature that addresses the issue of the plague. This literature is immensely diverse and includes reflections by theologians, jurists, ethicists, historians, travelers, and of course physicians as well. Each of these groups discussed plagues from their respective perspectives. While theologians and jurists concentrated on the proper attitude of a believer in terms of matters related to creed and ritual practice, historians and travelers concentrated on documenting actual incidents and relevant details in specific regions. Physicians, as expected, concentrated on understanding the disease in terms of diagnosis, prognosis, and treatment. The main sources of these reflections were twofold: scriptural references in the Qurān and Sunna of the Prophet; and lessons learned from actual incidents of plagues that triggered commentary from Muslim scholars over time. This body of literature is quite relevant to the recent Coronavirus pandemic because, in essence, it deals with the human condition as it faces existential threats and reveals important connections to the Islamic system of belief, practice, and morality.

This paper investigates some of the important ethical questions that emerged in connection with the Covid-19 pandemic in light of the various Muslim responses to this global emergency, mainly in the form of individual or collective fatwās as well as other types of normative institutional statements. It focuses on the ethical discussions surrounding some of the main measures that have been taken to fight the disease. In general, these measures can be divided into two main categories: those that aim at preventing the occurrence of the disease such as lockdown, quarantine, and social distancing mechanisms; and those that aim at treating individuals who have already contracted the disease. To these a third category is added, which includes measures that aim at ensuring appropriate and dignified handling of the dead bodies of individuals who died as a result of the disease. The paper traces the origins of the moral deliberations surrounding these measures in the Islamic normative tradition. For example, the preventive measures are located within classical discussions concerning earlier episodes of plagues as well as the religious status of contagion, while the therapeutic measures are located within discussions concerning the religious status of medical treatment and also the role of religious-devotional practices in treating illnesses. The paper argues that the ethical deliberations surrounding the measures that have been taken in response to the COVID-19 pandemic echo a longstanding two-pronged moral concern in the Islamic normative heritage; namely, to balance: religious and 
metaphysical dimensions of the scriptural sources with the practical implications of real incidents of plagues and pandemics; and the interests of individuals against the collective interests of groups and societies. While the paper underscores the normative background of recent Islamic deliberations on Covid-19, it also emphasizes the need to situate these deliberations within ongoing historical discussions concerning preceding episodes of plagues and pandemics. Moreover, these recent deliberations have to be placed within the broader modern scientific and medical context, which has introduced important new variables, and consequently has also given rise to a host of new questions. The paper, therefore, offers an illustrative example of how the Islamic normative tradition continues to adapt in order to accommodate contemporary needs and changes. In this case, while recent Islamic deliberations on the Coronavirus pandemic are inspired and informed by the religio-moral discussions undergirding issues such as plagues, diseases, and appropriate attitudes of believers in response to these events, these deliberations also reflect serious efforts to incorporate the findings and recommendations of medical experts and public health institutions. ${ }^{2}$

\section{Background in the Islamic Tradition: Plagues and Pandemics}

In Arabic the term for the plague (ța $\bar{u} \bar{u} n)$ is derived from the origin that denotes piercing with a sharp tool or weapon such as an arrow. The term is also used to describe a situation involving the death of many people as a result of a common disease, which explains its connection with the term $w a b \bar{a}$. While ța $\bar{u}$ n is mostly reserved for the plague, the more generic term $w a b \bar{a}^{\prime}$ is usually used to denote an epidemic, especially one of large scale impact. Occasionally, however, these two terms were also used interchangeably as synonyms. This is mainly because whenever plagues erupted, they often resulted in a large number of victims (Conrad 1982). ${ }^{3}$ Most of the symptoms that pre-modern sources

2 A full exploration of the relationship between Islam and modern science or medicine lies beyond the scope of this paper. This issue involves at least three main questions: history of science and medicine in the Islamic tradition (Dallal 2010; Saliba 2011; Pormann and Savage-Smith 2007); current debates on Islam and science (Iqbal 2007; Guessoum 2010), and the increasing authority of scientific and medical knowledge, particularly in relationship to religious or juristic knowledge, as manifested in various bioethical deliberations (Sachedina 2009).

3 Ibn Hajar (d. 852/1449) is one of the main sources on this topic. Not only did he write a comprehensive treatise on the issue of the plague but he also gave an eyewitness account of one of the main incidents of the plague during his lifetime. He discusses the various opinions on the distinction between $t \bar{a}\left(\bar{u} n\right.$ and $w a b \bar{a}^{\prime}$ in two sections of his treatise on the plague. In the 
give for the plague correspond with the bubonic type, which is accompanied by inflammatory swelling mainly in certain parts of the body such as the groin and armpits, although other symptoms were also recorded, which correspond with other types of the plague. ${ }^{4}$ Islamic historical sources are replete with references to a series of plagues that hit different regions at different times. Also, the ethical literature that emerged in connection with plague pandemics often traces the main incidents of these pandemics in different period of Islamic history. For example, al-Nawawī (d. 676/1277) lists five main plagues during the early period of Islam. The first occurred during the lifetime of the Prophet in the city of al-Madāin in Iraq in the year 6/627-628, which is known as the plague of Shirawayh. ${ }^{5}$ The second was the famous plague of 'Amwās during the reign of 'Umar (r. 13-23/634-44) in the year 18/639, which killed about 2500o. ${ }^{6}$ The third occurred during the time of 'Abd Allāh ibn al-Zubayr (r. 64-73/683$692)$ in the year 69/688, which is known as the sweeping plague (al-tāa ún al-jārif). ${ }^{7}$ It is reported that for three days during this plague pandemic, about 70.000 people died each day. The fourth occurred in Iraq and Syria in the year $87 / 706$, which is known as the plague of the girls (al-fataya $\bar{t}$ ) because most

first section, after providing the various opinions, he concludes with two main points. The first is that there are several types of $t \bar{a} \bar{u} \bar{n}$, following the various recorded opinions on the symptoms. The second is that $w a b \bar{a}$, following the views of Ibn Sinnā (Avicenna, d. 428/1037) and Ibn al-Nafis (d. 687/1288) that he quotes, results mostly from contamination in the air, water, or in the environment in general (Ibn Hajar n.d., 95-101). In the second section, he argues that $w a b \bar{a}^{\prime}$ is more generic than $t \bar{a} \bar{u}$, mainly on the basis of Prophetic reports indicating that $t \bar{c} \bar{c} \bar{u} n$ does not occur in Medina (Ibn Ḥajar n.d., 102-108). The same point was also made by al-Nawawī (d. 676/1277) (al-Nawawī 1929, 14: 204).

4 For example, Ibn Hajar notes that the plague comes in four main types: a form of swelling that occurs, especially in certain parts of the body such as the groin or armpits; a form of ulcer or blister that occurs, also especially in the groin or armpits; and a disease that causes body organs to erode as is the case with leprosy; a disease that drains the soul such as angina (dhabhah) (Ibn Ḥajar n.d., 99-100). He describes dhabha as pain in the throat or ulcer that grows inside of it and may cause its blockage and that may result in the obstruction of breathing (Ibn Ḥajar n.d., 172).

5 Al-Mas'ūdī (d. 345/956) mentions this plague but does not mention a date for it (al-Mas'ū ū 2010, 1:223).

6 Al-Nawawi lists two views on whether this incident took place in year $17 / 638$ or 18/639 but he seems to support the latter view. In his historical account, al-Tabarī (d. 310/923) lists this event in year $17 / 638$ but he also includes reports indicating that it occurred in year 18/639 (al-Ṭabarī 20o8, 2:685-8). Ibn al-Athīr (d. 630/1233), however, lists it in year 18/639 (Ibn al-Athīr 2009, 2:272).

7 Ibn Kathïr (d. 774/1373) mentioned the sweeping plague (al-țā ün al-järif) of the year 69/688, which killed, among others, Abū al-Aswad al-Du'alī (d. probably 69/688-9) who is known as the founder of Arabic grammar (Ibn Kathīr 2005, 8:2294; Ibn Khallikān 2009, 2:539). 
of the victims were young girls. ${ }^{8}$ The fifth plague pandemic occurred in the year 131/749 (al-Nawawī 1929, 1:106; Ibn Ḥajar n.d., 361-370). Historical sources include references to other incidents of plague pandemics, which shows that these incidents were quite frequent or recurrent rather than rare or sporadic episodes. The main difference, however, remained in the scope of these pandemics and the magnitude of their impact. ${ }^{9}$

Islamic ethical discussions on the themes of plagues and pandemics grew out of commentaries on specific references in the foundational sources: the Qur'ān and Prophetic reports. These references center around a number of moral questions such as: justification for these incidents; relationship between these events and divine destiny as well as the proper view and attitude of a believer towards these events; scope of human intervention and the extent to which such intervention is obligatory; impact of these incidents on ritual deeds; and finally impact of these incidents on social interpersonal interactions. Eventually, these questions received detailed and more systematic treatment in particular theological and juristic genres. This paper cannot do justice in reflecting either the depth or full extent of the discussions surrounding these questions but in this section I only hope to show how these classical discussions continue to shape and inform recent discussions on the Coronavirus pandemic.

The ethical justification for plague pandemics includes several points such as the origins, causes, as well as (divine) objectives behind these events. With regard to the origin of the plague, the Prophet is reported to have described it in one hadith as a form of punishment or torment (rijz) that was sent to the earlier nations. This hadith has several narrations that address the extent to which any occurrence of the plague can be related to that origin and the

8 Ibn al-Athīr refers to the plague that occurred in this year in Bașra as al-țāūn al-jārif as well (Ibn al-Athīr 2009, 4:264).

9 For example, al-Nawawi also lists other incidents that occurred in between these five main plague pandemics. Ibn Hajar provides a longer list that includes the plagues that occurred up until the one that he witnessed in his lifetime in 833/1429. In the medieval period, the Black Death stands out as an important turning point in world history. Documentation of this major pandemic abound in historical records, including ones from the various Muslim regions (Dols 1977). For example, the famous historian Ibn Khaldūn (d. 8o8/1406) describes the plague that occurred in the mid-8th/14th century as a cosmic event that brought massive death and destruction (Ibn Khaldūn 2004, 52). Similarly, the famous traveler Ibn Bațtūța (d. 770/1368) reports in his travels certain incidents that he witnessed during the greatest plague (al-țā'ün al-a'zam) in Damascus in 749/1348 such as congregational prayers in certain mosques. According to Ibn Bațtūta, 2000 deaths were reported per day, while in Egypt the number reached 24.00o in one day (Ibn Bațtuța 1997, 1:325-326). For reports on this plague in Egypt, see al-Maqrīzī 1997, 4: 69-99 and in Syria, see Ibn Kathīr 2005, 14:4072-4075. 
punitive intent of the plague. For example, in one narration it is described as the remnant of the punishment that was sent to the earlier nations. In another, it is indicated that after it was sent as a form of punishment for the earlier nations, part of it remained on earth, so it emerges and then disappears intermittently. Going back to the relationship between a plague and an epidemic, some narrations mention the term waba $\bar{a}^{3}$ not $t \bar{a} \bar{u}^{\top} \bar{n}$ as a form of torment, which makes these discussions relevant to any type of epidemic not just the plague (Ibn Hajar n.d., 74-76). ${ }^{10}$ The term rijz is mentioned in the Qurān several times, mainly to denote torment or torture, particularly in connection with the punishment that earlier nations received due to their refusal to heed the messages brought to them by their Prophets. Commentaries on the Qur'ān often invoke that report in connection to the term rijz. For example, in his commentary on 2:59, al-Tabari (d. 310/923) indicates that the lexical meaning of the term rijz is torment ('adhāb), according to the people of Hijāz. He includes a view indicating that the term might also mean anger or wrath but most of the narrations that he cites support the view that it stands for torment. Moreover, according to the famous companion 'Abd Allāh ibn 'Abbās (d. c. 68/687-8), all Qur'ānic references to the term support this view. Al-Tabarī also cites the Prophetic report drawing the connection between the plague and the punishment sent to the earlier nations. While al-Ṭabarī sees a strong possibility that the punishment that was sent in this case was the plague in light of the Prophetic report mentioned above, he does not rule out the possibility that the punishment could have been sent in other forms as well, since the Qur'ān did not explicitly mention the term tạ $\bar{c} \bar{u} n$ in this particular case (al-Ṭabarī 2001, 1:729-731).11

10 According to the narration in Sahịh Muslim, when the Prophet was asked about the plague (al-țāiun), he responded by saying that "it is a rijz or 'adhāb that was sent to the Children of Israel or to those who were before you. If you hear that it occurred in a region, do not enter it and if it occurs in a place while you are in it, you should not leave it, in order to escape from it (the plague)" (al-Nawawī 1929, 14:204).

11 Other references to the term rijz in the Qurān are: 7:134; 7:135; 7:162; 8:11; 34:5; 45:11; and 29:34. Another important justification often mentioned in the religious discussions on the plague highlights its metaphysical origins as indicated in some Prophetic reports that it results from a sting (wakhz) by the jinn. According to Ibn Ḥajar, this explanation for the occurrence of the plague does not necessarily contradict the physical explanations and symptoms that the physicians describe, mainly because the sting by the jinn happens in an internal or invisible (bātinī) manner, which may give rise to other external and explicit symptoms. The physicians do not discuss this metaphysical dimension because it cannot be perceived by reason or experimentation as we know about it through the Prophetic reports only (Ibn Hajar n.d., 104-105). Similarly, Ibn al-Qayyim (d. 751/1350) also 
While repeated references in the Qurān and Prophetic reports show that punishment for earlier nations was sometimes meted out in the form of plague pandemics, other references indicate that the plague can also serve as a means of divine mercy for the believers, as mentioned in some narrations of the above mentioned hadith itself (Ibn Hajar n.d., 74-6). Other reports indicate that the person who dies because of the plague will receive the reward of a martyr. ${ }^{12}$ This characterization of the plague as a form of divine mercy and the great reward to be given to those who die because of it has to be located within the larger conceptualization of illness, and difficulties or hardships in general, as a form of testing. The theme of testing (ibtila $)$ as a means of verification of one's faith and sincerity is a major theme in religious traditions, which is certainly true in the case of Islam as well. ${ }^{13}$

The relationship between the plague, or pandemics in general, and divine destiny was partly addressed in the famous incident of the plague that hit Syria at the time of 'Umar. Reports of this incident indicate that when 'Umar was on his way to Syria, the leaders of the army went out to meet him and inform him about the occurrence of the plague. When he consulted with his companions, there was a disagreement. While some were of the opinion that they should proceed to Syria according to the original plan they had when they set out from Medina, others were of the opinion that they should go back and not take the risk of transmitting the disease to more Muslims. After further deliberations, 'Umar decided to go back to Medina and spare the people with him the risk of contracting the disease. At that moment, it is reported that the leader of the army, Abū 'Ubayda ibn al-Jarrāh (d. 18/639), posed an exclamatory question

addresses this aspect of the plague while discussing the distinction between $t \bar{a} \bar{u} \bar{n}$ and $w a b \bar{a}$. He supports the view that $t \bar{a} c \bar{u} n$ is more specific than $w a b \bar{a}^{3}$ and notes that the term $t \bar{a}$ ün has three main connotations: the apparent, explicit, and external symptoms that physicians explain; death caused by the disease; and the cause behind it or the purpose it is meant to serve, as indicated in some reports that it was sent as a form of punishment for the earlier nations, or that it is caused by the sting (wakhz) of jinn (Ibn al-Qayyim $1998,4: 36)$. For a more detailed account on the classical discussions on the nature of the plague, see Conrad 1982.

12 According to the report in the collection of al-Bukhārī (d. 256/870), when 'Ā'isha (d. 58/678), the Prophet's wife, asked him about the plague, the Prophet noted: "It was a torment that God would send to whomever He wills but He made it a mercy for the believers. Upon its occurrence, if a person stays in his own locality believing that nothing would happen to him except that which was written for him, he will receive a reward similar to that of a martyr" (Ibn Hajar 1970, 10:192).

13 This is at least one aspect of the question of theodicy in major theological traditions. For an overview of Islamic approaches towards theodicy, see Hoover 2007, 177-210. 
on whether by doing this 'Umar would be fleeing from God's destiny. 'Umar responded by noting that he would be fleeing from God's destiny to God's destiny. The report concludes with a Prophetic advice not to enter an affected area or get out of it if one is already inside it. According to the report, 'Umar was not aware of this statement by the Prophet before he made the decision to go back to Medina. When it was brought to his attention by another companion, 'Abd al-Rahmmān ibn 'Awf (d. 32/652-653), he was pleased that his decision corresponded with this advice (Ibn Hajar 1970, 10:179; al-Nawawī 1929, 14:208210). This report has inspired discussions on the extent to which one can exercise one's agency in response to an action or event perceived to be part of divine destiny. ${ }^{14}$

In addition to this report on the plague of 'Amwās, and the attitude of 'Umar, several other Prophetic reports address the issue of contagion, which have also shaped Islamic discussions on the plague and on contagious diseases in general. The main question that Muslim scholars debated was how to reconcile competing reports on the reality and also impact of contagion. While some reports seem to deny the existence of contagion, others support and confirm its effect. For example, in one report, the Prophet is quoted as having negated the impact of contagion ('adwa) (Ibn Hajar 1970, 10:158). In another report with similar wording, a Bedouin poses this question: "Oh, Prophet of God, what about the (healthy) camels that run in the sand like deer but upon mixing with mangy camels they become mangy too?" The Prophet then responded by saying: "and who brought the disease to the first (mangy camel)?" Here the Prophet is pointing out the original cause of the disease beyond other apparent causes such as contagion. On the other hand, in another report, the Prophet gave this advice: "let not a diseased one mix with a healthy one," which seems to acknowledge the reality and impact of contagion. In order to reconcile the seeming conflict between these reports on contagion, several commentators noted that the reports indicating the negation of contagion do not deny the reality or impact of contagion in itself but they rather denote denial of the independent efficacy of contagion (apart from or beyond divine will). On the other hand, the reports discouraging the mixing between the healthy and the sick aim to guard against the development of a belief in the independent efficacy of contagion (Ibn Ḥajar 1970, 10:141-2; al-Nawawī 1929, 14:213-4).15

14 For more on this incident and on Islamic discussions on contagion, see Conrad 1998, 2000, and Stearns 2017.

15 Ibn Hajar mentioned four main opinions on the issue of contagion: that diseases can cause contagion by their nature; that diseases cause contagion by means of something that God created in them; that diseases cause contagion not by their nature but by means of a custom that God established with these diseases; and that diseases do not cause 
As much as the Islamic ethical discussions on plague pandemics were shaped by specific references in the textual sources that explain their causes as well as relationship to contagion and divine destiny, they were also shaped by wider or broader topics such as the religious-moral status of medical treatment $(\operatorname{tad} \bar{a} w \bar{\imath})$ and also the extent to which such treatment can be supplemented or even supplanted by religious or devotional deeds. The main ethical tension that the issue of medical treatment involves is whether it would conflict with reliance on God as the Ultimate Healer. This tension, however, was often addressed with reference to several Prophetic reports that recommend medical treatment as a way to cure diseases. These reports show that medical treatment can be a means to actualize the causes that God instituted in the universe. As noted above with regard to contagion, medical treatment should not be perceived as an independent cause and that is why it should be pursued along with recommended devotional deeds such as prayers and supplications to God (Ibn Ḥajar 1970, 10:134-136; al-Nawawī 1929, 14:191).16

Historical accounts of the various epidemics and plague pandemics that struck different regions at different times show how Islamic normative discussions on topics such as contagion, illness, and medical treatment shaped the attitudes of Muslims during these times. One of the common themes in historiographical surveys of plague pandemics in the Muslim World is the role of Islam in promoting a fatalistic attitude in the face of recurrent plague eruptions. Recent studies, however, provide a more nuanced reading of Muslim

contagion by their nature at all but it is God who causes it. With the exception of the first opinion, he notes that Muslim scholars tend to support one of the other three opinions, while he chose the last one on the basis of the Prophetic reports negating the independent efficacy of contagion (Ibn Hajar n.d., 343-344). On the other hand, the Andalusian scholar-physician Ibn al-Khațib (d. 776/1374) in his treatise on the plague supported the reality and efficacy of contagion, mainly on the basis of actual practical experience (Ibn al-Khațīb 2015, 70-71). For a more detailed account on pre-modern Islamic discussions on contagion, mainly in North Africa and al-Andalus, see Stearns 2011.

16 Islamic ethical discussions on the plague often include recommended manners and etiquettes that a Muslim should follow during the time of a plague. This includes specific prayers and formulas of remembrance of God (dhikr) that should be performed in these situations. For example, in his treatise on the plague, Ibn Hajar includes a section entitled "ethics pertaining to patients afflicted by the plague or other types of diseases." From these ethics, he includes the following: seeking help from God in attaining health and warding off disease; showing patience and satisfaction with God's destiny; thinking well of God and developing faith in His omnipotence (Ibn Hajar n.d., 345-57). This part of the plague literature is also related to the question of theodicy in the sense that illness, as a form of difficulty or evil, often has moral lessons as well. For example, the famous Shāfi $\overline{1}$ jurist al-'Izz Ibn 'Abd al-Salām (d. 662/1262) compiled a short treatise to discuss the benefits of calamities, in which he enumerated seventeen advantages (al-Sulamī 2016). 
reactions towards epidemics. For example, in her book on the plague within the early Ottoman context, Nukhet Varlik questions the common charge of Turkish fatalism and points out how Ottoman sources reveal important debates that reflect a multiplicity of opinions. Moreover, she traces the changing perceptions of the plague from a supernatural to a natural event that can be addressed and overcome (Varlik 2015, 82; 208).

Historiographical accounts of epidemics and pandemics also show that contagion was not solely debated among religious scholars in light of the competing scriptural references but it was also disputed among the physicians themselves. Disagreements among medical experts on the existence of contagion fueled an extended debate on the means by which diseases were transmitted, which continued until the modern period. For example, in his recent study on the application of modern medical procedures in 19th century Egypt, Khaled Fahmy notes that medical professionals in Egypt, similar to their counterparts in Europe, were divided into two groups: those who supported the efficacy of contagion, and those who thought that diseases were transmitted by means of environmental factors such as bad air or miasma (Fahmy 2018, 38). With the gradual enforcement of public health measures during the frequent epidemics that hit Egypt in the 19th century, quarantines were consistently imposed as precautionary preventive measures, even by medical officials who did not believe in contagion. ${ }^{17}$ When some religious scholars initially objected to quarantine measures on religious grounds confirming belief in divine providence, the Egyptian ruler, Mehmed Ali Paşa (Muhammad 'Alī, r. 12201265/1805-1848), responded with counter religious arguments highlighting the importance of taking necessary precautions to fight the epidemic. Fahmy argues that initial negative reactions against quarantines were not solely due to religious objections but rather due to the disruptive impact of these forceful measures. Eventually, however, fatwās were issued in support of quarantine measures aiming at safeguarding public health, while emphasizing the importance of upholding relevant Sharîa rules concerning the proper treatment of those who are ill as well as respectful handling of the dead bodies of deceased

17 Fahmy argues that the implementation of these public health measures during the reign of Mehmed Ali Paşa was not solely driven by particular religious or scientific-medical understanding of contagion but also by important social and political factors - aiming, for example, at preserving the health and well-being of state officials and military troops (Fahmy 2018, 54-55). It was only at the end of the 19th century that a modern scientific understanding of the plague was established when the bacteria causing the disease (Yersinia pestis) was discovered (Varlik 2015, 17-54). 
epidemic victims (Fahmy 2018, 56-62). ${ }^{18}$ For the purpose of this paper, these historical accounts are important in highlighting significant areas of continuity and development. They reveal the range of diversity within ongoing normative discussions concerning issues such as the plague, contagion, and divine destiny. Moreover, they clearly demonstrate that these normative discussions often did not happen in a vacuum but rather in connection with other attending social and cultural factors.

\section{Overview of the Islamic Responses to the COVID-19 Pandemic}

Numerous normative pronouncements have been issued throughout the Muslim world to answer the various questions that emerged since the beginning of the epidemic in early 2020. This already sizeable literature of normative pronouncements shows the wide range of moral questions that occupied Muslim religious scholars and ethicists as the disease quickly turned into a global public health crisis, with ramifications touching every aspect of people's lives. These pronouncements include individual as well as collective fatwās, institutional statements (by both national and transnational institutions), and professional guidelines and recommendations (Șabrī 2020). While some fatwās concentrated on a single issue such as prayer, others addressed multiple issues. Major fatwā institutions have also convened special joint meetings between the jurists and medical experts to discuss pressing questions associated with the various medical concerns that the pandemic triggered. Due to the difficulty of covering the full scope of the normative literature that has been generated, this paper will concentrate mainly on two meetings as illustrative examples: the first was convened by the International Islamic Fiqh Academy of the Organization of Islamic Cooperation (IIFA) on April 16 (IIFA 2020a); and the second was hosted by the European Council for Fatwa and Research (ECFR) between March 25-28 (ECFR 2020a, 2020b). The concluding statements of these two meetings reveal the range of issues that the participants addressed and the adopted recommendations show that they aimed to cover the various juristic, medical, and public policy dimensions of the Covid-19 pandemic. These two statements have been chosen for more than one reason. The first is their relatively comprehensive thematic scope, as they both cover most of the issues that have been addressed in individual or specific fatwās. The second

18 For another account on public health measures in 19th century Egypt, see Kuhnke 1990 and Sonbol 1991. For additional accounts on plagues and epidemics in different regions, see Robarts 2016, Speziale 2006, and Gallagher 1983. 
is their broad geographic scope. While both institutions are often classified as transnational or international, they tend to address different segments of the global Muslim population. IIFA, as one can judge from its members and participating scholars, addresses mainly Muslims in Muslim-majority regions. On the other hand, ECFR, as its name suggests, addresses Muslims in minority setting in the West in general and in Europe in particular. Other reasons also have to do with collective institutional fatwās as compared to individual ones. For example, collective fatwās tend to include more diversity than individual fatwās. Also, when it comes to certain issues that require technical expertise, collective fatwās often incorporate the opinion of subject-matter experts. This, however, does not mean that these two statements are exhaustive in terms of the range of religio-moral questions that have been raised in connection with the coviD-19 pandemic or that they represent all the opinions that have been articulated by different Muslim authorities. But, for the purpose of this paper, they offer a representative sample of opinions on some of the main questions that the pandemic has triggered.

To begin with, and in terms of structure, each of these two statements has its own distinctive features. While the IIFA statement is formulated as a statement that includes a number of (24) bullet points, the ECFR is formulated as a single document that comprises multiple fatwās. It should be noted that the ECFR held a subsequent meeting in April to follow up on the earlier meeting that was held in March. The total number of fatwās that were issued in these two meetings is 34:1-22 in the first (ECFR 2020a); and 22-34 in the second (ECFR 2O2Ob). Both meetings reflect a significant effort to integrate verified scientific information about the disease that the virus causes and how to limit its transmission through the participation of medical experts representing a number of relevant specialties. ${ }^{19}$ The two statements that were issued after these meetings include introductions on relevant medical (IIFA) and theoethical (ECFR) background information. For example, the IIFA begins with an overview of the disease, its characteristics, and symptoms. It highlights two main points: the highly infectious nature of the disease that the virus causes (therefore the importance of avoiding exposure through social distancing and maintaining personal hygiene routines); and the incomplete or evolving nature of scientific research on this new virus, which defied efforts to understand or

19 For example, a number of physicians participated in the IIFA meeting such as Muhammad 'Alī al-Bārr, Ḥassān Shamsī Bāshā, and 'Abd Allāh al-Jūdī. In the ECFr statement, the following experts are listed among the participants: Yahyā Makkī (virology, France), Anas Shākir (anesthesia and resuscitation, France), Muhammad al-Hamṣ (internal medicine and acute disease, UK), and Mundhir Rajab (internal medicine, cardiology, and family medicine, Germany). 
combat the disease. On the other hand, the ECFR statement begins with a synopsis of the Islamic view of plagues and epidemics. The statement places these incidents within the larger context of God's established norms and customs in the universe, which are in turn tied to a set of higher values and objectives. These established norms include testing with adversities and calamities, which are meant to deter people against works of mischief and corruption. They also include boons or bounties, which are meant to serve as rewards for good deeds and also as incentives to pursue the path of obedience and godliness. The statement indicates that the Coronavirus pandemic can be seen as a form of testing with adversity in response to acts such as: abuse of the environment, depletion of natural resources, and violation of the moral values that aim to safeguard and preserve these resources. These activities have created a general state of imbalance in the cosmic order and this type of testing with adversity should serve as a reminder for people to ponder over the consequences of their deeds and to find ways to fix past mistakes.

\section{Preventive Measures}

A quick survey of the normative Islamic literature that was generated in response to the COVID-19 pandemic reveals that the major bulk of this literature addresses the preventive measures that should be undertaken in order to minimize exposure to the virus. These preventive measures aim to limit or, to the extent possible, prevent social gatherings or collective interpersonal interactions involving any type of physical contact. From a religious perspective, these measures affect almost all the Islamic ritual acts, particularly congregational prayers. Other similar questions were raised about the possibility of suspending pilgrimage to the holy shrines in Mecca and Medina in light of the travel restrictions that were imposed to prevent mass transmission of the disease. Apart from this concentration on the impact of the pandemic on ritual prayer and pilgrimage to the holy shrines, there were also questions about the other ritual pillars of Islam: fasting and charity. For example, some questions were raised about whether the pandemic can be considered a valid excuse for not observing the ritual fast during the month of Ramadiann. Similarly, some questions were raised about whether the pandemic can provide enough justification to pay the annual ritual charity in advance in order to assist those in need, especially those who have been adversely affected by the pandemic.

Most of the fatwās and statements that were issued in connection with the outbreak of the Coronavirus concentrated on its impact on holding congregational prayers in mosques. One of the earliest examples was the statement 
that was issued by al-Azhar's Senior Scholars' Assembly on March 15, which was dedicated mainly to this question, as evident from its title "permissibility of suspending Friday and congregational prayers for the purpose of protecting people from the Coronavirus" (Șabrī 2020, 13-15). The statement begins with an acknowledgement of the contagious nature of the disease and its transmission even through asymptomatic carriers. With its transformation into a global pandemic, on the basis of confirmed medical reports, the statement indicates, the disease constitutes a significant risk against people's lives. Since one of the main objectives of Shari $a$ is to protect life, the fatwa emphasizes that all necessary precautions to achieve this objective should be taken. Under these circumstances, Friday as well as congregational prayers can be suspended in order to limit the spread of the disease. In support of this view, the statement cites three sets of Prophetic reports indicating that Friday and congregational prayers can be suspended for certain excuses. The first set pertains to circumstances in which going to the mosque becomes difficult or extremely inconvenient, as it is the case with situations involving heavy rain, illness, or concern over one's safety, property, or family. The second set includes reports about the proper attitude of a believer in the outbreak of a plague: one should not move to or out of a plague-stricken region. The third set of reports, indicates that one should not attend a congregational prayer in case one's presence harms others, or becomes a source of discomfort for others, as understood from reports pointing out that one should not attend collective prayers in the mosque after eating certain types of food, especially those containing ingredients such as garlic or onion. Appealing to a priori analogy, the fatwa $\bar{a}$ indicates that the inconvenience caused by the unpleasant smell of garlic or onion, which can be a valid reason for not attending congregational prayer, is much less harmful than a contagious disease that can be a significant risk against people's lives. The fatwa indicates that the call to prayer should still be made, with the possibility of adding a phrase alerting people that they should pray at home instead of going to the mosque. It also points out that individuals can pray together with family members, in their own homes. The fatwa encourages people to follow public health instructions and guidelines in order to limit the circulation of the virus. Finally, the fatwa concludes by urging people to increase their good deeds, provide assistance to the sick and the needy, and to turn to God in prayer by imploring Him to lift this disease.

A similar statement on the permissibility of suspending Friday and congregational prayers was issued by the Senior Scholars' Assembly in Saudi Arabia on March 17 (Șabrī 2020, 16-18). In support of this view, the fatwā does not only cite Prophetic reports, but also relevant Qurānic verses. While the fatwa 
by al-Azhar's Senior Scholars' Assembly invokes the notion of the higher objectives of Sharîa, the Saudi statement cites specific Quraanic references emphasizing the importance of protecting one's life (Q 2:195; 4:29). The Saudi statement cites two sets of Prophetic reports. The first includes reports on the issue of contagion, while highlighting the passages that confirm its efficacy. The second includes reports on the plague, which was mentioned also in al-

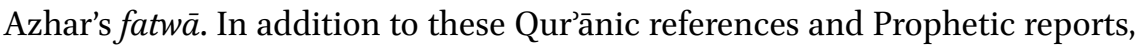
the Saudi statement also appeals to famous legal maxims on the need to prevent or remove harm: harm shall neither be inflicted nor reciprocated; and harm shall be warded off as much as possible.

Both of these statements by al-Azhar and the Saudi Assembly of Senior Scholars indicate that the alternative to the congregational Friday prayer when performed in the mosque in normal circumstances is the performance of the regular noon prayer at home, either individually or with one's family. Further details about the preventive measures impacting congregational prayer, however, were included in the statements by the IIFA and the ECFR. Both statements are relatively lengthier and they deal with multiple issues in comparison with the other single-topic fatwa as and statements. On the impact of the pandemic on prayer, both statements confirm the permissibility of suspending Friday and congregational prayers in mosques. For example, the IIFA statement endorses the precautionary stipulations by public health authorities banning all types of social gatherings. By way of implementing these stipulations, the statement supports the suspension of congregational prayers such as the five daily prayers as well as the Friday and Eid prayers. The statement advocates this view in the spirit of true reliance on God by respecting rather than neglecting the causes. If physicians and medical experts are unanimous that social gatherings lead to the spread of the infection and the contraction of the disease, then all types of gatherings should be avoided (point 7 ). The call to prayer (Adhān) can still be made, with the addition of the phrase mentioned above instructing worshippers to pray at home (point 8). In lieu of the Friday prayer, regular noon prayer should be offered at home. It is emphasized that the regular Friday prayer cannot be offered at home, since that would defeat its communal purpose. In the meantime, authorities can arrange for Friday prayer to be held at a specific mosque with a limited number of people in attendance, after taking necessary precautions, which can then be broadcast in order to uphold the symbolic significance of this important weekly ritual. Viewers at home can listen to the sermon but they should not follow the imam in prayer in this case, which lacks the necessary condition of physical proximity between the imam and those who follow him in prayer (point 9). 
Similarly, the ECFR statement supports the permissibility of suspending congregational prayers in light of the numerous textual proofs that emphasize the preservation of life and, by extension, physical health, even over the fulfillment of religious obligations in cases of conflict (ECFR 2O2Oa). Religious concessions to shorten prayer or to forgo ritual fasting in cases of travel or sickness are in line with this principle. The statement appeals also to the famous legal maxims on harm (harm shall be removed), distress (distress begets ease), and necessities (necessities override prohibitions). Moreover, the statement cites Prophetic reports on these three themes: contagion, with a particular focus on passages confirming rather than denying its effect; the plague, highlighting the warning against leaving or moving into infected areas; and permissibility of missing congregational prayer in case of valid excuses such as heavy rain, sickness, or fear (fatwā no. 3). The ECFR statement includes also several fatwās dedicated to specific questions on Friday and congregational prayers such as the possibility of holding Friday prayer electronically (fatwā no. 4), performance of the Friday prayer at home (fatwā no. 5), and the validity of holding congregational prayer while maintaining a one-meter distance between individuals ( fatwā no. 7).

Pilgrimage to the holy shrines in Mecca and Medina was the other main ritual practice, after prayer, that was heavily impacted by the preventive measures to fight the Coronavirus. In light of travel bans and limitations to freedom of movement, many questions were raised over whether the annual pilgrimage to the holy shrines would still be held. For example, the ECFR statement includes a fatwa answering a question about the possibility of postponing pilgrimage this year, assuming that the pandemic would continue until the time of the Hajj season and that travel would be possible (fatwa no. 31). The fatwa emphasizes the point that the obligation to perform pilgrimage to the sacred shrine in Mecca is predicated on the conditions of ability (qudra) or feasibility (istița $a)$, which includes three main elements: physical health, financial means, and absence of impending dangers that may threaten one's safety or life. The fatwa indicates that if pilgrimage is suspended due to concerns over the transmission of the infection, it will be permissible to postpone the performance of this act of worship until the following year. It should be noted that the Saudi government suspended travel into the country for the purpose of visiting the holy sites and performance of 'umra, shortly after the outbreak of the pandemic (in late February 2020). As indicated above in the statement by the Senior Scholars' Assembly, these sites, along with all mosques, were already closed for congregational prayers. It was not, however, clear whether travel would resume and these sites would be reopened for the annual pilgrimage 
season. ${ }^{20}$ Eventually, on June 22, the Saudi government took a decision not to suspend the pilgrimage but to allow it only for a limited number of pilgrims, from among those already residing in Saudi Arabia (Wizārat al-Ḥajj wa-l-'Umra 2020). Both of these decisions by the Saudi government restricting travel into the country for health concerns were endorsed by IIFA (IIFA 2020b; IIFA 2O2Oc).

With regard to the impact of the pandemic on fasting, several questions were raised on whether observing ritual fasting during the month of Ramaḍān would increase one's chance of contracting the disease. The IIFA includes a passage (no. 11) on the impact of fasting on one's general state of health. It indicates that in the absence of verified scientific evidence suggesting that fasting negatively affects one's immunity against the disease, breaking the fast due to the Coronavirus pandemic would be impermissible. It also indicates that the case of those who are infected or those who are sick in general should be evaluated in light of their own circumstances on the basis of the medical expertise of their treating physicians. The statement recognizes that in certain cases medical staff can become quite exhausted, which may affect their ability to observe the ritual fast during daytime. Under these circumstances, medical professionals can break the fast and make up for the missed days afterwards.

The ECFR deliberations also addressed the impact of the pandemic on fasting. The issue of fasting was actually investigated in the subsequent meeting that was held in April to resume the discussions that started during the earlier meeting that was held in March (ECFR 2O2Ob). The theme of fasting was central to this subsequent meeting, which was singled out in its title, although this subsequent meeting also investigated other issues as well. The fact that the meeting was held shortly before the beginning of the month of Ramadiann in the midst of a global pandemic that medical experts did not know much about, and scientists everywhere were racing to decipher, left many questions open for speculations. One of these questions had to do with best ways to boost the immune system to enable one's body to resist or fight the virus. This general concern over ways to enhance bodily immunity was clearly reflected on social media platforms, which were inundated with all types of recipes and prescriptions on best ways to deal with the disease. Some of the fatwās in the ECFR statement actually address some of these scattered news. For example, one fatwa is given in response to a question over circulated reports about the need to keep the body hydrated. According to these reports, drinking fluids is

20 Some calls were made urging the Saudi government to consider suspending the Hajj season due to the COVID-19 pandemic (Moosa 2020). 
highly recommended in the battle against the infection. The fatwa indicates that, after consultation with physicians and medical specialists, the potential negative impact of fasting on the dehydration of the body, which may increase one's chances of being infected, was not verified. On the contrary, the fatwa explains, fasting has been found to have a positive impact on strengthening bodily immunity, and subsequently one's ability to fight diseases in general (fatwā no. 22). The fatwā reiterates juristic rules on concessions that can be granted in case of sickness. The main point of the fatwāa, however, is to debunk the causal connection between fasting and increased chances of infection with the Coronavirus. It concludes with an advice to maintain social distancing and to avoid customary practices in the month of Ramaḍan such as family visits, invitations for meals, and other types of communal celebrations. Another fatwa is given in response to a question about the possibility of suspending the ritual fasting of Ramadān or postponing it until the end of the pandemic (fatwā no. 23). The fatwa denies this possibility and emphasizes that the ritual fasting is strictly bound to the ninth month of the Arabic-Hijri calendar (Ramaḍan), as borne out by numerous textual indications in the foundational sources of Islam (e.g. Qurān 2:185). As is the case with the other acts of worship, the fatwa $\bar{a}$ indicates, timing is an integral part of the devotional dimension of these acts. The fatwa concludes by reiterating the health benefits of fasting, which can be read as an implicit recommendation to maintain ritual fasting in its regular time rather than changing it.

The Coronavirus pandemic has had massive economic ramifications, affecting almost all sectors and activities. In light of this enormous economic impact, several questions were raised on whether the obligatory alms (zakät) as well as other types of charities can be used to assist in covering expenses associated with efforts to deal with the pandemic. Other questions were raised on whether these funds could be deployed to help those who have been negatively affected. For example, the IIFA statement includes a passage on this issue (point 12), which also indicates the permissibility of paying the annual obligatory alms in advance, before the specific or regular time marking the passing of a full lunar year. This is meant to encourage those who have the means to provide immediate support to those who are in need. Similarly, the ECFR includes a fatwa on the permissibility of paying the obligatory alms in advance, which is deemed not only permissible but also meritorious in these circumstances, especially in light of the fact that many of the charitable activities in the West depend on these funds (fatwā no. 9). On the other hand, another fatwā is given on the permissibility of paying the compensation for not observing the fasting before the beginning of Ramaḍann (for people who are chronically ill and unable to fast). 
The fatwa emphasizes the timing of such compensation and that it becomes obligatory only when Ramaḍān begins ( fatwā no. 29). Another fatwā is given in response to a question about the possibility of paying the obligatory alms and charities to hospitals or nursing homes for the elderly (fatwa no. 30). The fatwa makes a distinction between the obligatory alms, which should be paid to the stipulated categories mentioned in the Qurān (9:6o), and other types of charities, which can be used to support all philanthropic causes including hospitals and other entities that provide necessary care especially to poor segments of the society. In general, fatwās on the Coronavirus often highlight Islamic injunctions that underscore the importance of social solidarity and the need to support the poor and those who are insolvent, especially in times of crisis.

Apart from these implications on Islamic ritual practices, the normative pronouncements that were generated in response to the pandemic tend to reinforce the preventive measures that have been suggested by medical experts as well as public health authorities. This is particularly the case in the statements that were issued after joint deliberations between Islamic religious scholars and medical professionals, as is the case with the statements by IIFA and ECFR. For example, the IIFA statement clearly notes that governments can impose all necessary restrictions that aim to benefit the general public (point 4). This may include procedures such as travel bans, limiting the circulation of cash notes or coins, suspension of educational activities, and closure of shopping venues. This would also include the imposition of lockdowns as well as necessary social distancing procedures that aim to prevent or minimize exposure to the virus. The justification provided here is the legal maxim indicating that the ruler's (government) authority on the ruled is tied to the achievement of utility, especially at the public or collective level (al-Suyūṭi 2004, 1:278; Ibn Nujaym n.d., 131-132).

Preventive measures include the isolation of those who are already infected and also those who had contact with them. The IIFA indicates that imposition of quarantine in these cases is obligatory in order to prevent the transmission of the virus. Moreover, the statement notes, it would be impermissible for infected individuals to conceal this information either from authorities or from family members. Those who fail to do so can be subjected to a discretionary penalty. According to the statement, infected individuals who act carelessly should be reported to the authorities to ensure that proper procedures are implemented (point 6). The ECFR statement also emphasizes the importance of adhering to quarantine and lockdown procedures in infected areas. Due to the lethal nature of the disease that the virus causes, going out of homes should be carefully regulated. According to the statement, negligent behavior that causes the 
transmission of the infection to others, and subsequently their death, can serve as grounds for the penalty of unintentional killing ( fatwa no. 13). On the other hand, an infected person should not be liable to this penalty if he ends up infecting others inadvertently, despite taking all necessary precautions ( fatwa no. 16). In order to limit chances for the spread of the virus, and in line with the precautions that public health officials recommended, the IIFA highlights the significance of basic preventive procedures such as regular washing of hands with water and soap, wearing of masks and gloves, and frequent disinfection techniques (point 5). Similarly, the ECFR statement recommends strict and careful adherence to social distancing mechanisms, including the avoidance of handshaking, hugging, or kissing - following medical confirmations on the role of these practices in the transmission of the infection (fatwa no. 15).

Therapeutic Measures

One of the important steps in charting an effective therapeutic plan for the disease, which has often been reiterated both in the medical and normative instructions, is the development of a mature and balanced attitude towards the pandemic, one that avoids both careless underestimation of its risks but also unnecessary exaggeration of its dangers. Such attitude would require proper understanding of the nature of the disease on the basis of reliable and trusted sources. For example, the IIFA statement denounces the circulation of inaccurate information and rumors that instill fear and anxiety. It emphasizes the importance of educational efforts to raise awareness about the virus and the diseases it causes, which should also reassure the public and reinforce hope and optimism. It recognizes that the most important resource in the fight against the pandemic is the immunity system and that its health depends on biological as well as psychological factors, which together contribute to one's overall well-being (point 16).

While taking necessary precautions to limit the spread of the pandemic is important in general whether in the implementation of preventive or therapeutic measures, ethicists advise against panicking or exaggerated emotional reactions. Multiple news reports show how extreme fear of or obsession with the disease can lead to various forms of bullying against vulnerable patients fighting the disease, their families, or even improper and disrespectful attitudes towards the bodies of deceased COVID-19 patients. The ECFR statement includes a fatwa $\bar{a}$ that warns against all forms of bullying against Coronavirus patients and their families, particularly within the medical or clinical setting. 
It draws a distinction between taking necessary precautions on the one hand, and showing extreme aversion towards patients and loathing them, on the other. Even if one cannot provide necessary care or help, one should at least show kindness and empathy (fatwa no. 11). Coronaphobia has emerged as a new term that denotes negative psychological effects of the pandemic and researchers have started to examine empirical factors associated with this new phenomenon. For example, a recent study reveals a strong correlation between coronaphobia and a range of psychological problems that can eventually trigger suicidal ideas. The study points out the need for healthcare professionals to pay attention to this new phenomenon, due to the severe consequences that may result if it is otherwise overlooked or ignored (Lee et al. 2020). These consequences do not only impact patients but also their families as well as care providers. With isolation and quarantine procedures, patients are separated from their family members and this sometimes means that they would die alone, leaving behind survivors who have to manage mixed feelings such as loss, grief, anger, and guilt (Harlan et al. 2020; Schairer 2020). Medical professional also suffer from fatigue or extreme tiredness. In these situations, clinicians who face serious challenges and who sometimes have to make tough, even life and death, decisions on the spot become susceptible to various types of emotional distress and also serious psychological problems such as delayed anxiety, traumatic memories, and depression (Rappaport 2020).

The normative Islamic literature surrounding the Coronavirus pandemic places special emphasis on the role of faith or religious beliefs in the development of a proper attitude towards the pandemic. The significance of these beliefs lies in the fact that they shape one's outlook towards life, view of the world, and also ability to find answers to the difficult questions that often emerge in challenging circumstances. Some of these questions revolve around the issue of suffering and the extent to which it can be reconciled with a religious belief in a merciful and benevolent god. For example, the ECFR statement includes two fatwās that address the theo-ethical dimensions of pandemics. The first ( fatwa no. 1) answers a question about the moral lessons that diseases or catastrophes in general serve and whether they should be seen as forms of divine punishment. The fatwa explains that catastrophes and all types of unpleasant events should be understood as integral part of life on this earth. These events befall both individuals and communities and they are meant to

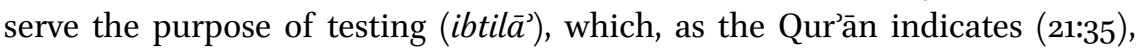
can come in the form of either fortunes or misfortunes. Testing by adversities and misfortunes in this sense is not meant to be a form of torture per se but it can have several objectives, such as: reminding people of God's blessings; 
pointing out man's constant need for God and the importance of seeking refuge with Him; and warning against the commission of sin or disobedience. The second fatw $\bar{a}$ (no. 2) is more explicit about the role of religion in understanding and also dealing with the Coronavirus pandemic. The fatwa begins by noting that the pandemic is a cosmic event that affects the entire world and that requires the deployment of all types of resources to defeat it. Faith, the fatwo explains, as the most important source of spiritual energy, can be quite helpful in addressing this global threat by strengthening people's confidence in their ability to withstand challenges and hardships. Moreover, religion also includes references to specific practices that can support the efforts to combat the pandemic such as: emphasis on personal hygiene and cleanliness; health measures associated with contagion and quarantine; and emphasis on one's role in the fulfillment of social and communal responsibilities.

The role of spirituality and religious practices is often highlighted when one feels helpless in the face of diseases of unknown cures or at times of difficulties in general. The ECFR includes a fatwā on the permissibility and significance of religious incantation (ruqya) as a means of protection from the pandemic. The fatwa begins with a general warning that the term ruqya is often confused with other cultural or traditional practices that tend to conflict with Sharîa and its objectives. In essence, the fatwa $\bar{a}$ indicates, ruqya consists in sincere prayer and supplication to God. Moreover, it should be done by the patient himself/ herself, especially during pandemics. The fatwa concludes by emphasizing the importance of following reliable medical procedures on the basis of trusted sources as the primary and most appropriate method of dealing with the disease ( fatwā no. 12). Similarly, the IIFA points out the importance of prayer and developing firm belief in divine destiny but it does not include any explicit reference to ruqya (point 23).

Apart from these general remarks on one's proper attitude during the pandemic, the importance of one's spiritual-psychological state, and also the role of religious deeds in the fight against the disease, the normative literature also addresses specific medical notions and therapeutic procedures. One of these notions that emerged in connection with the Coronavirus pandemic is herd or community immunity, as a method to combat the disease. Within the early weeks of the pandemic the term became part of the pandemic-specific vocabulary that infiltrated public discussions, along with expressions such as social distancing, flattening the curve, and super spreader, which were previously used mostly by medical experts only (Dardick 2020). In its basic definition, herd immunity refers to the situation when a large segment of the population becomes immune to a disease either through vaccination or previous exposure 
to the disease. Transmission recedes only when the number of immune people increases. In the absence of a vaccine or an effective cure for the Coronavirus, some argued that lifting restrictions and increasing exposure can be a means to achieve herd immunity. Medical experts, however, warn that seeking community immunity through this means is risky because the large number of patients would exhaust medical resources with no guarantees for ending the transmission of the disease. The term became notorious when it moved from technical medical discussions to political disputes and controversies, as some politicians, such as the British Prime Minister Boris Johnson, championed it as a solution to avoid or overcome the massive consequences of shutting down economies. Also, some countries such as Sweden, for example, have actually adopted this approach. As medical experts note, one of the main problems with this application of herd immunity is its impact on vulnerable segments of the population with weakened immunity such as the elderly and those who have chronic diseases. According to Amesh Adalja, senior scholar at Johns Hopkins Center for Health Security: "In Stockholm, they did not reach herd immunity, and the price you pay for that is that you get transmission chains that end up landing on a vulnerable individual who then can be hospitalized or die from this" (Dardick 2020).

Scientists continue to investigate how herd immunity through mass exposure can work in the fight against the Coronavirus pandemic, particularly by determining the exact threshold at which it can function more efficiently. This approach towards the achievement of community immunity is much more challenging in comparison with normal situations when it is achieved by a more standardized manner through vaccination. One major problem that scientists face as they fight the virus in real time is what they describe as heterogeneity or the idea that: "the effects of the coronavirus are not linear. The virus affects individuals and populations in very different ways ... People are exposed to different amounts of the virus, in different contexts, via different routes. A virus that is new to the species creates more variety in immune responses" (Hamblin 2020). But, with the proven heavy toll of lifting restrictions prematurely in countries such as Sweden, Brazil, and the United States either with the hope of achieving herd immunity through mass transmission of the infection or due to a belief in a conspiracy theory that denies the reality of this disease - most medical experts support the idea of achieving community immunity through vaccination rather than through mass exposure to the disease. The standard advice offered consistently by experts, in the absence of safe and effective vaccination, consists in the implementation of basic preventive measures such as social distancing, disinfection, wearing of masks, 
and regular washing of hands (Dardick 2020). In line with these guidelines, the IIFA statement denounces the idea of achieving community immunity through mass exposure to the virus due to its harmful impact on vulnerable groups. According to the statement, failure to provide care for treatable conditions, before they develop further complications, would amount to recklessness and negligence by the standards of Sharîa (point 3).

During the pandemic, the large number of patients that required hospitalization and even access to intensive medical care created added pressure on medical staff and increased demand on scarce medical resources. Allocation of medical resources is an important theme in medical ethics but during a pandemic, it is one of the challenging aspects of everyday reality in hospitals and medical centers. Discussions surrounding this theme, along with other similar ones such as setting priorities and rationing often involve balancing important ethical principles in the field of medical ethics, particularly justice and other principles such as autonomy, beneficence, and nonmaleficence. In their influential book on principles of biomedical ethics, Beauchamp and Childress compare two main approaches in case of competition for medical resources: a utilitarian strategy that promotes maximum benefits for both patients and the society; and an egalitarian strategy that emphasizes the equal worth of individuals and also fair opportunity. They argue that these two approaches can be combined in actual policies and procedures through further specifications (Beauchamp and Childress 2019, 308). The IIFA indicates that governments should work on securing critical care equipment such as ventilators. In regulating access to these resources, the statement notes, clinicians should adhere to relevant medical as well as ethical standards. The statement recognizes the fact that physicians are sometimes forced to make choices between patients. In these circumstances, physicians should use judgment on the basis of medical expertise. If they have to choose between equally deserving patients, a decision can be made by lot drawing (point 18). The ECFR includes a fatwā in response to a question on setting priorities in cases of competition for medical treatment. The fatwa indicates that physicians should follow the medical regulations and bylaws adopted in the institutions in which they operate. In case they have to make their own decisions, they have to do so in light of relevant medical, ethical, and humanitarian standards. In this light, necessary medical equipment should not be taken from one patient and given to another incoming patient. If the medical team is undecided on who should be treated first, priority should be set by precedence, unless a patient's condition is deemed hopeless. Priority can also be given to those who require immediate attention over those who can wait and to those who are responsive to treatment 
over those who are unresponsive. In these situations, according to the fatwa decisions should be made on the basis of preponderance of probability and medical expertise (fatwā no. 18). Looking at these statements in light of the approaches that Beauchamp and Childress discuss, the IIFA seems to adopt an egalitarian approach, while the ECFR combines both the utilitarian and egalitarian approaches. However, considering the nature of these normative pronouncements, they tend to be formulated in a generic style that would allow further specification in particular procedures, guidelines, or policies.

The pandemic has not only increased demand for intensive care equipment but it has also turned basic medical supplies such as masks and gloves into rare commodities with daily reports on fierce competitions in local and international markets to secure these necessities. In many cases, governments had to regulate access to basic medical supplies by rationing and other similar arrangements. The IIFA statement calls upon governments as well as charitable organizations to work on securing these supplies in adequate quantities, especially for medical professionals, either through manufacturing or importing them. The statement also urges sharing these supplies with those in need throughout the world and participating in the effort to combat this global pandemic. It condemns hoarding these items, as well as all necessary goods, during the pandemic in order to manipulate prices in order to achieve profits by taking advantage of people in need. In these situations, the statement indicates, governments should impose rules to regulate distribution of these supplies and ensure that they are sold at fair prices (points 19, 21).

One of the most important topics in connection with the therapeutic measures undertaken to fight the pandemic is the need to develop an effective vaccine. The global race to discover a safe and effective vaccine for the covid-19 virus has created an unprecedented global scramble among research centers and major pharmaceutical conglomerates. As of June 29, 202O, the wHo listed 17 candidate vaccines in clinical assessment and 132 others in pre-clinical assessment (WHO 202Oa). On November 9, 202O, the discovery of the first successful vaccine was announced by its developers (Pfizer and BioNTech), which was described as a "great day for science and humanity." Subsequently, similar announcements for the discovery of other vaccines were also made in several countries across the globe. From an ethical perspective, the topic of vaccination often raises a number of moral questions that have to do with access, distribution, and also autonomy - whether individuals can choose not to be vaccinated. From an Islamic perspective, one of the main ethical questions has to do with the ingredients of a particular vaccine and whether it contains a religiously prohibited item (Padela 2013). The global pressure and rush to 
develop a vaccine for the coronavirus has raised additional moral questions that have to do with the balance between the urgent need for this vaccine and the time and resources that it would require. The IIFA statement emphasizes that experiments for the development of the vaccine should adhere to accepted ethical and scientific standards (point 20 ). ${ }^{21}$

While the world was waiting for a safe and effective vaccination against the CoviD-19 virus, physicians and health authorities strove to develop adequate therapeutic methods and drugs to help patients boost their immunity system in order to be able to fight the virus. One of the most important techniques was the injection of the plasma of recovered COviD-19 patients due to its inclusion of the needed antibodies that would enable a patient's immunity system to fight the infection. In many countries, however, demand for this plasma, far exceeded available supply, which turned this plasma into a rare commodity and created a black market for it. Desperate patients and their families were sometimes forced to pay large amounts in order to secure this plasma. From an Islamic ethical perspective, this situation raised a question on the permissibility of the sale of plasma from recovered patients, especially in a pandemic situation. Al-Azhar's International Center for Electronic Fatwa issued a statement about this issue, according to which withholding the plasma by recovered CoviD-19 patients, without a valid excuse, was deemed impermissible and sinful (Buhayrī 2020). A subsequent statement, however, explicitly declared the sale of the plasma of recovered COVID-19 patients to be prohibited ('Abd al-Raḥmān 2020).

In comparison with the preventive measures, the coverage of therapeutic measures in the IIFA and ECFR statements, and in the fatwa literature in general, is less comprehensive. This difference shows clearly the extent to which religious scholars tend to concede matters of technical medical nature to medical experts. Both statements give the impression that the conveners aimed to communicate agreement and consensus between the religious scholars and medical experts. Another possible reason also has to do with the fact

21 The statement refers to earlier discussions undertaken by the IIFA in its 17th session. These discussions, were in part, based on similar discussions by the International Organization for Medical Sciences in 2004, which preceded the formulation of the International Islamic Code for Medical and Health Ethics. This Code includes commentary, from an Islamic point of view, on a number of ethical guidelines for biomedical research involving human subjects that were developed by the Council for International Organizations of Medical Sciences (CIOMS) (El-Gendy 2005, 121-251). The Code endorses the three general ethical principles that should govern biomedical research involving human subjects: respect for persons, beneficence, and justice (El-Gendy 2005, 144-147). 
that medical experts worldwide, at least at the time of these meetings, did not know much about the disease or best ways to deal with it.

\section{$6 \quad$ Handling of Dead Bodies}

One of the important, and perhaps distinctive, aspects of the Coronavirus pandemic, and of pandemics in general, is the increased rate of fatality. Apart from the severe social and psychological toll of the loss in human life, the high rate of death cases creates added pressure on health as well as other designated facilities, to secure the necessary resources to ensure proper and dignified handling of the dead, as expected in normal circumstances. In this respect, the changing conditions of life under the pandemic affect the deceased as much as they affect the living. News reports, particularly from countries that witnessed relatively higher percentages of infection and death cases, were replete with deplorable details showing how the Covid-19 pandemic created additional complexities for the victims and deprived their family members from being together with them at the last moments of their lives. As a worker in a funeral home in Italy put it: "This pandemic kills twice. First, it isolates you from your loved ones right before you die. Then, it does not allow anyone to get closure" (Bettiza 2020).

As noted above, exaggerated emotional reactions towards the disease can backfire and can negatively affect not only CoviD-19 patients and their families but also how the bodies of deceased patients are treated. In some cases, these feelings resulted in refusal to allow the bodies of victims to be buried in regular or nearby cemeteries, despite official assurances confirming the safety of burial procedures and the lack of any public health hazards. In some regions special police forces had to be deployed to prevent protesters from obstructing funeral processions, and in others several people were prosecuted for preventing the burial of Coronavirus victims. Ironically, some of these victims were from among the fallen medical staff (Sullivan 2020; Zaki 2020). Despite prosecutions and formal condemnation by senior religious leadership almost everywhere (Al-Dawoody and Finegan 2020), anxiety still continued in many cases at the communal and popular levels, which at times created a stigma surrounding the deceased patients and their families (Hanif 2020).

In the face of the rising numbers of death cases and the various complexities that this situation may cause, safety becomes the highest priority and governments often devise specific protocols to meet the need to dispose of dead bodies in efficient, yet (religiously) appropriate ways. From an Islamic perspective, and in light of the specific rules concerning the handling of dead 
bodies, a significant portion of the normative literature that was produced in response to the Coronavirus pandemic, was dedicated to this topic. In general, the issue of funerals (al-janäiz) includes several points such as washing, shrouding, prayer, burial, and also consolation etiquettes. The IIFA statement indicates that washing and shrouding of the dead body is obligatory. However, if washing becomes unfeasible, sprinkling of water would be sufficient, otherwise, the obligation to wash the body can be substituted by dry ablution with dust (tayammum). If this also becomes difficult, this requirement can be dropped and preventive health procedures should be followed. The same can also be observed with regard to shrouding (point 13). The statement also points out the possibility that washing of dead bodies in these cases may be undertaken by remotely-controlled devices if proper rules are implemented, should such devices become available. The statement urges Muslim technical experts to work on the development of these tools. Similarly, the ECFR statement includes a fatwa on this issue, which gives preference to the view that the dead bodies of individuals who died because of the Coronavirus can be buried without washing or even dry ablution, in order to minimize chances of infection through direct contact with the body of the deceased person. According to this fatw $\bar{a}$, achieving the interest of those who are living, by protecting their life, takes priority over observing the rules pertaining to washing the bodies of those who have died. Moreover, the communicable nature of the disease would require special training on how to avoid the transmission of the infection, which might not be available to those undertaking this procedure. In these circumstances, the dead body can be buried in the body bag or casket, within which it was placed in the hospital, after the offering of the funeral prayer. The funeral prayer is a collective duty, which can be performed by those who are present and able but it can also be performed in absentia, either individually or in congregation ( fatwā no. 19).

With regard to burial, the standard rule provides that it should be done in the region where death took place. In other words, there is no obligation to move the body to a specific place or region such as country of origin. Burial should be done in a Muslim cemetery but the EFCR notes that this would depend on availability. If burial in a designated Muslim cemetery becomes difficult, the body of a Muslim can still be buried in a non-Muslim cemetery, especially during emergencies such as pandemics. According to the ECFR statement what is of prime benefit for individuals after death is their deeds, as the Qur'ān clearly indicates (53:39), not the place where their bodies are buried (fatwā no. 19). This would also apply even if the deceased person left a written will indicating preference for burial in a different (distant) locality that would require air 
travel ( fatwās 21). Both the IIFA (point 13) and ECFR (fatwā no. 20) statements do not approve of cremation. According to the EFCR statement, burial in the ground is the most appropriate method befitting human dignity. Muslims should explain how important this is and ensure that the bodies of deceased Muslims are not cremated. In another fatwa $\bar{a}$, answering a question in case a government imposes cremation, it is indicated that authorities often honor religious and cultural values in these situations and therefore Muslims should request burial instead of cremation. However, if cremation is undertaken, the funeral prayer should be performed beforehand. Otherwise, the prayer can still be performed afterwards or also in absentia. The ECFR statement includes a fatwa on the possibility of burial in concrete chambers or structures on top of the ground instead of the usual holes that are dug in the ground. The fatwa indicates that this would be possible in cases of necessity and in the absence of alternatives conforming with the Islamic rules of burial, provided that bodies are treated with appropriate dignity and respect (fatwa no. 34). The ECFR statement urges Muslims living in the West to write their wills indicating that following death, bodies should be treated according to relevant Islamic rules ( fatwā no. 28).

The pandemic has not only impacted how dead bodies are handled but it has also influenced how people show support to survivors and family members of the deceased. In the new digital era, which is marked, among other things, by the ubiquity of social media platforms, the pandemic has enhanced the capacity of these platforms even further as viable alternatives for direct physical interaction. Expression of consolation as well as other types of communications surrounding mourning and bereavement have shifted in many ways to digital forms through social networking applications. This interesting development has also been reflected in the normative literature. For example, the IIFA statement observes that consolation of bereaved friends and family members is praiseworthy but in the time of a pandemic this social duty can be fulfilled through telephone calls or digital forms of communication in lieu of visits in order to limit chances for the circulation of the infection (point 14).

\section{$7 \quad$ Concluding Remarks}

The Coronavirus pandemic has created one of the most serious public health crises in recent history. Within a few weeks of its emergence in China, it spread all over the world and left its impact on all aspects of people's lives. The high rate of infection has increased pressure on medical resources and services, and 
intensified demand for basic medical supplies. For the current generation, the pandemic has brought to memory the legacy of major pestilences both in the pre-modern and modern periods. Islamic ethical deliberations on the Covid19 pandemic build on an existing tradition that emerged in connection with preceding incidents of epidemics, especially those associated with the plague. This tradition began with commentaries on specific references in the Islamic foundational sources, which eventually developed into detailed and systematic discussions across the various genres of the normative tradition including theology, jurisprudence, and mysticism. What is remarkable about this tradition is its continuous evolution in light of the recurrent episodes of epidemics, which made ongoing interpretation and reinterpretation necessary. The example of contagion illustrates this process of ongoing construction, as competing Prophetic reports have usually been reconciled in order to remove seeming contradictions - in line with a more active rather than passive or fatalistic attitude towards pandemics.

Islamic responses to the Covid-19 pandemic, therefore, should be situated within this ongoing and evolving ethical tradition, deriving from both normative and empirical sources. These recent responses also reflect important changes and transformations that the Islamic normative discourses have undergone in the modern period. As the two statements issued by the IIFA and the ECFR manifest, the authority structure in the modern period has been reconfigured to give more room for collective deliberations and institutional interdisciplinary formulations. Moreover, these statements reveal the extent to which increasingly normative pronouncements integrate modern scientificmedical knowledge and also how much religious scholars collaborate with public health authorities, at the local and global levels. In other words, as much as these statements build on the extended Islamic moral tradition, they also strive to fulfill the necessary conditions for the "continuing relevancy" of the tradition, as the late historian Marshal Hodgson put it, by seeking to meet the needs of contemporary Muslims and to address their emerging questions (Hodgson 1977, 1:34).

\section{Bibliography}

Beauchap, Tom L. and James F. Childress. 2019. Principles of Biomedical Ethics, eighth edition. Oxford: Oxford University Press.

Bettiza, Sophia. 2020. "Coronavirus: How Covid-19 is denying dignity to the dead in Italy. BBC News, March 25, 2020. www.bbc.com/news/health-52031539. 
Buhayrī, Aḥmad. 2020. "Fatwā min al-Azhar bi-Sha’n Tabarru' al-Muta‘āīn min Kurūnā bi-l-Bilāzmā." Al-Mașrī al-Yawm, June 3, 2020. www.almasryalyoum.com/news/ details/1984276.

CDC. n.d. "1918 Pandemic (HiN1 virus)." Accessed July 7, 2O2O. www.cdc.gov/flu/ pandemic-resources/1918-pandemic-hını.html.

Conrad, Lawrence I. 1982. "Ṭa'ūn and Wabā' Conceptions of Plague and Pestilence in Early Islam." Journal of the Economic and Social History of the Orient 25(3): 268-307.

Conrad, Lawrence I. 1998. "Umar at Sargh: The Evolution of an Umayyad Tradition on Flight from the Plague." In Story-Telling in the Framework of Non-Fictional Arabic Literature, edited by Stefan Leder, 488-528. Wiesbaden: Harrassowitz.

Conrad, Lawrence I. 200o. "A Ninth-Century Muslim Scholar's Discussion of Contagion.” In Contagion: Perspectives from Pre-Modern Societies, edited by Lawrence Conrad and Dominik Wujastyk, 163-177. Aldershot: Ashgate.

Dallal, Ahmad. 2010. Islam, Science, and the Challenge of History. New Haven, CT: Yale University Press.

Dardick, Hal. 2020. "What is Herd Immunity? And How Do We Get There on COVID-19?" Chicago Tribune, July 17, 2020. www.chicagotribune.com/coronavirus/ ct-cb-coronavirus-covid-herd-immunity-explained-20200717-jr2waugpzzgmh of 4pazrclfe5q-story.html.

Al-Dawoody, Ahmed and Oran Finegan. 2020. "COVID-19 and Islamic Burial Laws: Safeguarding Dignity of the Dead." Humanitarian Law and Policy. Accessed July 19, 2020. https://blogs.icrc.org/law-and-policy/2020/04/30/covid-19-islamic -burial-laws/.

Dols, Michael W. 1974. "Plague in Early Islamic History." Journal of the American Oriental Society $94(3): 371-383$.

Dols, Michael W. 1977. The Black Death in the Middle East. Princeton: Princeton University Press.

ECFR. 2020a. "Al-Mustajaddāt al-Fiqhiyya li-Nāzilat Fayrūs Kurūnā COVID-19." البيان-الختامي-للدورة-الطارئة/Occessed July 15, 2020. www.e-cfr.org/blog/2020/O4 ثالثال/.

ECFR. 202ob. "Aḥkām al-Ṣiyām wa-Mustajaddātih fī Ḍaw' Nāzilat Fayrūs Kurūnā COVID-19." Accessed July 16, 2020. www.e-cfr.org/blog/2020/04/17/ أحكام-الصيام ا-في-ضوء-فيروس-كورونا

El-Gendy, Ahmad Rajai, ed. 2005. The International Islamic Code for Medical and Health Ethics. Kuwait: Islamic Organization for Medical Sciences.

Fahmy, Khaled. 2018. In Quest of Justice: Islamic Law and Forensic Medicine in Modern Egypt. Oakland, CA: University of California Press.

Gallagher, Nancy Elizabeth. 1983. Medicine and Power in Tunisia, 1780-1900. Cambridge: Cambridge University Press. 
Green, Monica. 2014. "Taking 'Pandemic' Seriously: Making the Black Death Global." The Medieval Globe 1(1): 27-61.

Guessoum, Nidhal. 2010. Islam's Quantum Question: Reconciling Muslim Tradition and Modern Science. London: I.B. Tauris.

Hamblin, James. 2020. "A New Understanding of Herd Immunity." The Atlantic, July 13, 2020. www.theatlantic.com/health/archive/2020/o7/herd-immunity-corona virus $/ 614035 /$.

Hanif, Mohammed. 2020. "What's With All the COVID-Death Shaming? Some Pakistanis Won't Say They are Losing Family Members to the Pandemic Because They Don't Want to Bury the Bodies Alone." New York Times, July 16, 2020. www .nytimes.com/2020/o7/16/opinion/coronavirus-pakistan-death.html.

Harlan, Chico, Stefano Pitrelli and Gianluca Panella. 2020. "Avoiding the Loneliness of a Coronavirus Hospital Death." The Washington Post, April 22, 2020. www .washingtonpost.com/world/2020/04/22/avoiding-loneliness-coronavirus-hospital -death/?arc404=true.

Hodgson, Marshall G. 1977. The Venture of Islam: Conscience and History in a World Civilization, 3 vols. Chicago, IL: The University of Chicago Press.

Hoover, Jon. 2007. Ibn Taymiyya's Theodicy of Perpetual Optimism. Leiden: Brill.

Ibn al-Athīr. 20og. Al-Kāmil fi al-Tārīkh, edited by Samīr Shams, 13 vols. Beirut: Dār Șādir.

Ibn Baț̣ūṭa, Muḥammad ibn 'Abd Allāh. 1997. Riḥlat Ibn Baț̣uț̣h al-Musammāh Tuhfat al-Nuzzār fì Gharāib al-Amșār wa-'Ajāìb al-Asfār, edited by 'Abd al-Hādī al-Tāzī, 5 vols. Rabat: Akādīmiyyat al-Mamlaka al-Maghribiyya.

Ibn Ḥajar al-'Asqalānī, Aḥmad ibn 'Alī. 1970. Fatḥ al-Bārī bi-Sharh Ṣaḥịh al-Bukhārī, 13 vols., edited by 'Abd al-'Azīz ibn 'Abd Allāh ibn Bāz, Muhammad Fu’ād 'Abd al-Bāqī and Muhibb al-Dīn al-Khațīb. Beirut: Dār al-Ma'rifa.

Ibn Ḥajar al-'Asqalānī, Aḥmad ibn 'Alī. n.d. Badhl al-Māēun fí Fạ̣l al-Ṭāūn, edited by Aḥmad 'Ișām 'Abd al-Qādir al-Kātib. Riyadh: Dār al-Āṣima.

Ibn Kathīr, Ismācīl Ibn 'Umar. 2005. Al-Bidāya wa-l-Nihāya, edited by Suhayl Zakkār, 14 parts in 7 vols. Beirut: Dār Ṣādir.

Ibn Khallikān, Aḥmad ibn Muhammad. 20og. Wafayāt al-Acyān wa-Anbāa Abnä al-Zamān, edited by Iḥsān 'Abbās, 8 vols. Beirut: Dār Șādir.

Ibn Khaldūn, 'Abd al-Raḥmān ibn Muḥammad. 2004. Muqaddimat Ibn Khaldūn, edited by Hāmid Aḥmad Ṭāhir. Cairo: Dār al-Fajr lil-Turāth.

Ibn al-Khațīb, Muḥammad ibn 'Abd Allāh. 2015. Muqni'at al-Sā̉il 'an al-Marạ̣ al-Ḥāill, edited by Ḥayāt Qārra. Rabat: Manshūrāt Dār al-Amān.

Ibn Nujaym, Zayn al-'Ābidīn ibn Ibrāhīm.n.d. Al-Ashbāh wa-l-Nazā̄ir 'alā Madhhab Abī Hanīfa al-Nu'mān. Cairo: al-Maktaba al-Tawfiqiyya. 
Ibn Qayyim al-Jawziyya, Muḥammad ibn Abī Bakr. 1998. Zād al-Māād fı̀ Hady Khayr $a l$ - Ibād, edited by Shu'ayb al-Arnā'ūt and 'Abd al-Qādir al-Arnā'ūt, 6 vols. Beirut: Mu'assassat al-Risāla.

IIFA. 2020a. "Tawșiyyāt al-Nadwa al-Ṭibbiyya al-Fiqhiyya al-Thāniya li-Hadhā al-Āmm bi-'Unwān 'Fayrūs Kurūnā al-Mustajadd (COVID-19) wa-mā Yata'allaq bihi min Mu'ālajāt Ṭibbiyya wa-Aḥkām Shar'iyya." Accessed July 15, 2020. www.iifa-aifi .org/5254.html.

IIFA. 202ob. "Bayān Majma' al-Fiqh al-Islāmī al-Dawlī bi-Sha’n Ta'līq al-Dukhūl ilā al-Arāọ̄ī al-Sa'ūdiyya li-Aghrāọ al-'Umra wa-Ziyārat al-Masjid al-Nabawī al-Sharīf Mu'aqqatan." Accessed July 16, 2020. www.iifa-aifi.org/523o.html.

IIFA. 202Oc. "Bayān Majma al-Fiqh al-Islāmī al-Dawlī 'an Ḥajj 1441." Accessed July 16, 2020. www.iifa-aifi.org/527o.html.

Iqbal, Muzaffar. 2007. Science and Islam. Westport, CT: Greenwood Press.

Kuhnke, LaVerne. 199o. Lives at Risk: Public Health in Nineteenth-Century Egypt. Berkeley: University of California Press.

Lee, Sherman A., Mary C. Jobe, Amanda A. Mathis and Jeffrey A. Gibbons. 2020. "Incremental Validity of Coronaphobia: Coronavirus Anxiety Explains Depression, Generalized Anxiety, and Death Anxiety." Journal of Anxiety Disorders, published online July 1, 2020. www.ncbi.nlm.nih.gov/pmc/articles/PMC7328548/.

al-Maqrīzī, Aḥmad ibn 'Alī. 1997. Al-Sulūk li-Márifat Duwal al-Mulūk, edited by Muḥammad 'Abd al-Qādir 'Ațā, 8 vols. Beirut: Dār al-Kutub al-'Ilmiyya.

al-Mas'ūdī, 'Alī ibn al-Ḥusayn ibn 'Alī. 2010. Murūj al-Dhahab wa-Ma'ādin al-Jawhar, edited by 'Afîf Nāyif Ḥāṭūm, 4 vols. Beirut: Dār Ṣādir.

Moosa, Ebrahim. 2020. "Saudi Arabia Must Suspend the Hajj: The Presence of Millions of Pilgrims in Mecca and Medina will Have Lethal Consequences." New York Times, April 27, 2020. www.nytimes.com/2020/04/27/opinion/coronavirus-hajjpilgrimage.html.

al-Nawawī, Muhȳī al-Dīn ibn Sharaf. 1929. Șaḥịh Muslim bi-Sharh al-Nawawī, 18 vols. Cairo: al-Mațbaca al-Mișriyya.

Padela, Aasim. 2013. "Islamic Verdicts in Health Policy Discourse: Porcine-Based Vaccines as a Case Study." Zygon 48(3): 655-670.

Pormann, Peter E. and Emilie Savage-Smith. 2007. Medieval Islamic Medicine. Washington, DC: Georgetown University Press.

Rappaport, Nancy. 2020. "I'm Worried about the Psychological Toll on Health Care Workers. They Need Help." WBUR, April 16, 2020. www.wbur.org/cognoscenti/ 2020/04/16/support-health-care-workers-nancy-rappaport.

Robarts, Andrew. 2016. Migration and Disease in the Black Sea Region: Ottoman-Russian Relations in the Late Eighteenth and Early Nineteenth Centuries. New York: Bloomsbury Academic. 
Șabrī, Mas'ūd. 2020. Fatāwāa al-'Ulamā’ hawla Fayrūs Kurūnā. Cairo: Dār al-Bashīr.

Sachedina, Abdulaziz. 2009. Islamic Biomedical Ethics: Principles and Application. Oxford: Oxford University Press.

Saliba, George. 2011. Islamic Science and the Making of the European Renaissance. Cambridge, MA: MIT Press.

Schairer, Marilyn. 2020. "Coronavirus Patients Are Dying Alone, Leaving Loved Ones With Grief And Guilt.” WGBH, May 14, 2020. www.wgbh.org/news/local-news/ 2020/05/14/coronavirus-patients-are-dying-alone-leaving-loved-ones-with-grief -and-guilt.

Sonbol, Amira el-Azhary. 1991. The Creation of a Medical Profession in Egypt, 1800-1922. New York: Syracuse University Press.

Speziale, Salvatore. 2006. "Epidemics and Quarantine in Mediterranean Africa from the Eighteenth to the Mid-Nineteenth Century." Journal of Mediterranean Studies 16(1-2): 249-258.

Stearns, Justin. 2011. Infectious Ideas: Contagion in Premodern Islamic and Christian Thought in the Western Mediterranean. Baltimore: Johns Hopkins University Press.

Stearns, Justin. 2017. "Public Health, the State, and Religious Scholarship: Sovereignty in Idris al-Bidlisi's Arguments for Fleeing the Plague." In The Scaffolding of Sovereignty: Global and Aesthetic Perspectives on the History of a Concept, edited by Zvi Ben-Dor Benite, Stefanos Geroulanos and Nicole Jerr, 163-185. Columbia: Columbia University Press.

al-Sulamī, 'Izz al-Dīn 'Abd al-'Azīz ibn 'Abd al-Salām. 2016. Al-Fitan wa-l-Balāyāa wa-l-Miḥan wa-l-Razāyā. Damascus: Dār al-Fikr.

Sullivan, Michael. 2020. "Fearing Infection, Some in Indonesia Refuse Nearby Burial of Covid-19 Victims." National Public Radio, May 1, 2020. www.npr.org/sections/ coronavirus-live-updates/2020/05/o1/848956806/fearing-infection-some-in -indonesia-refuse-nearby-burial-of-covid-19-victims.

al-Suyūṭī, Jalāl al-Dīn 'Abd al-Raḥmān. 2004. Al-Ashbāh wa-l-Nazāàirfì Qawā'id wa-Furū' al-Shāfíiyya, edited by Muḥammad Muḥammad Tāmir and Ḥāfiz 'Āshūr Hạfiẓ, 2 parts in 1 vol. Cairo: Dār al-Salām.

al-Ṭabarī, Muhammad ibn Jarīr. 1422/2001. Tafsīr al-Tabarī:Jāmi' al-Bayān 'an Ta’wīl Āy al-Qur'ān, edited by 'Abd Allāh ibn Muḥsin al-Turkī, 26 vols. Cairo: Hajar lil-Ṭibā‘a wa-l-Nashr wa-l-Tawzī‘ wa-l-I'lān.

al-Ṭabarī, Muḥammad ibn Jarīr. 20o8. Tārīkh al-Ṭabarī, edited by Nawwāf al-Jarrāḥ. Beirut: Dār Ṣādir.

Taylor, Derrick Bryson. 2020. "A Timeline of the Coronavirus Pandemic" New York Times, July 21, 2020. www.nytimes.com/article/coronavirus-timeline.html.

Varlik, Nukhet. 2015. Plague and Empire in the Early Modern Mediterranean World: The Ottoman Experience, 1347-1600. Cambridge: Cambridge University Press. 
WHO. 2020a. "Timeline of WHO's response to COVID-19." Accessed July 10, 2020. www.who.int/news-room/detail/29-o6-2O2O-covidtimeline.

WH O. 2O2O-2021. "Coronavirus Disease (COVID-19) Dashboard." Accessed August 12, 2020. Last accessed February 22, 2021. https://covidig.who.int/.

Wizārat al-Ḥajj wa-l-'Umra. 2020. "Bayān Wizārat al-Ḥajj wa-l-'Umra." Accessed July 16, 2020. www.spa.gov.sa/2100944.

Zaki, Nada. 2020. "Egypt: Coronavirus Phobia." Ahramonline. April 14, 2020. http:// english.ahram.org.eg/NewsContent/5o/1201/367291/AlAhram-Weekly/Egypt/ Egypt-Coronavirus-phobia.aspx. 